\section{Odpowiedź na zagadkę ze str. 508}

\author{
Answer to the question page 508
}

Prawidłowa odpowiedź: C

Correct answer: C.

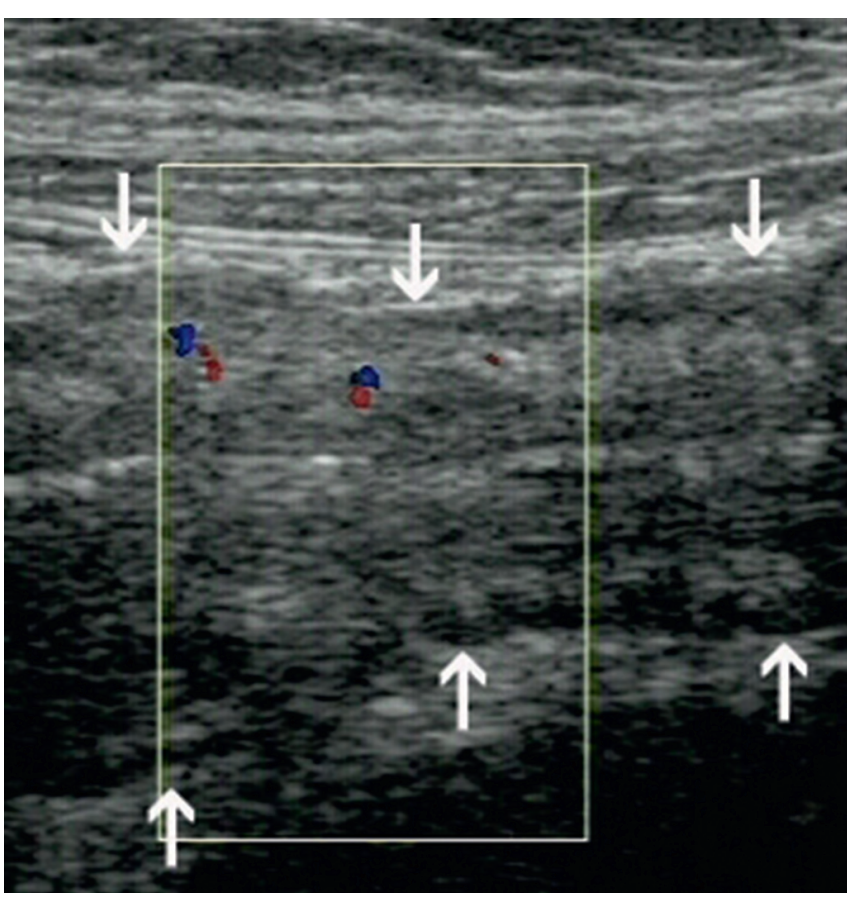

$\mathrm{W}$ moich zbiorach to już 32. pacjent $\mathrm{z}$ potwierdzoną serologicznie jersiniozą ${ }^{(1,2)}$. Podobne zmiany może spowodować kompylobakterioza, a także rzadko - salmonelloza, shigelloza czy Clostridium difficile. $\mathrm{W}$ tych trzech ostatnich jednostkach chorobowych zazwyczaj nie występuje adenomegalia krezkowa bądź też jest słabo wyrażona, natomiast obrzęk ścian obejmuje odcinek kątniczo-wstępniczy okrężnicy. Najczęstszą lokalizacją zmian w chorobie Leśniowskiego-Crohna (w około 50\%) i gruźlicy (w około 90\%) jest odcinek biodrowy jelita cienkiego. Spośród wymienionych patologii gruźlica jest obecnie najrzadziej spotykana. Zazwyczaj w tych przypadkach rozpoznanie ustala się na podstawie wycinków pobranych w trakcie kolonoskopii poszerzonej o ocenę wziernikową końcowego odcinka jelita krętego. Jednak w ostro przebiegających przypadkach najważniejsza jest umiejętność odróżnienia zapalenia wyrostka robaczkowego od infekcyjnego zapalenia jelita końcowego, ponieważ te dwie choroby wymagają innego postępowania lekarskiego. Takie możli-
Ryc. 2.

Fig. 2.

This is my $32^{\text {nd }}$ patient with serologically confirmed yersiniosis ${ }^{(1,2)}$. Compylobacteriosis and, more rarely, salmonellosis, shigellosis and Clostridium difficile may cause similar changes. In the last three disease entities, mesenteric adenomegaly is usually not present or not clearly visible and the wall edema affects the region of the cecum and ascending colon. The most common localization of lesions in Crohn's disease (in about 50\%) and in tuberculosis (in about 90\%) is the ileum. Tuberculosis is currently the rarest conditions out of these mentioned above. In such cases, the diagnosis is usually established on the basis of the specimens obtained during colonoscopy with the evaluation of the terminal ileum. In acute cases, however, the ability to distinguish between appendicitis and infectious terminal ileitis is crucial since these two diseases require different kinds of treatment. US examinations provide such a possibility. I can remember three patients treated surgically because of the suspicion of appendicitis, who were finally diagnosed with inflammation of the mesenteric lymph nodes. Fig. 1 B presents a color Doppler examination of both hyperemic terminal ileum and unchanged appendix (arrows). The visualization of this anatomic element allows for the differentiation between these two conditions. In about $20 \%$ of patients with appendicitis acuta, we observe slightly enlarged lymph nodes. Sometimes, reactive cecal wall thickening is also present. Due to these changes, the ability to conduct the US examination of the appendix, whose proper condition is observed in about $50 \%$ of the European population, is very important $t^{(3)}$. The proper assessment of the appendix in patients with Crohn's disease constitutes another problem. It is quite frequently evaluated - in 20-36\% of the cases (fig. 2). Sarrazin and Wilson ${ }^{(4)}$, in 1996, claimed that such a coincidence was demonstrated by enlarged appendix, but without any features of wall hyperemia in color Doppler examination. Ten years 
wości stwarza badanie USG. Pamiętam trzech chorych leczonych operacyjnie z podejrzeniem zapalenia wyrostka robaczkowego, u których ostatecznie rozpoznano zapalenie krezkowych węzłów chłonnych. Na ryc. 1 B ujęto w kolorowym dopplerze jednocześnie przekrwiony odcinek jelita końcowego i niezmieniony wyrostek robaczkowy (strzałki). Wykazanie tego elementu anatomicznego pozwala rozstrzygnąć, z którą z tych dwóch chorób mamy do czynienia. Mniej więcej u 20\% pacjentów z appendicitis acuta występują nieznacznie powiększone węzły chłonne. Niekiedy można też spotkać odczynowe zgrubienie ścian kątnicy. Ze względu na te zmiany bardzo ważna jest umiejętność przeprowadzania badania USG wyrostka robaczkowego ${ }^{(3)}$, którego prawidłowy stan w populacji europejskiej rozpoznaje się mniej więcej u $50 \%$ osób. Innym problemem jest właściwa interpretacja stanu wyrostka robaczkowego u pacjentów z chorobą Leśniowskiego-Crohna. Jest on dość często objęty tym procesem, bo w 20-36\% przypadków (ryc. 2). W 1996 roku Sarrazin i Wilson ${ }^{(4)}$ ustalili, że za taką koincydencją przemawia pogrubiały wyrostek, ale bez cech przekrwienia ścian w kolorowym dopplerze. Sytuacja skomplikowała się po 10 latach, gdy wyniki swoich badań dotyczących tego zagadnienia opublikowali Ripollés i wsp. ${ }^{(5)}$ Wyrostki robaczkowe uznane przez nich za objęte również przez proces ziarninowy w przebiegu choroby Leśniowskiego-Crohna wykazywały aż w $72 \%$ cechy przekrwienia (można sądzić, że przyczyną był czulszy doppler). Po zastosowaniu wielowariantowej analizy logistycznej danych autorzy stwierdzili, że zgrubienie jelita biodrowego powyżej $5 \mathrm{~mm}$ z cechami przekrwienia i jednoczesnym zgrubieniem i przekrwieniem ścian wyrostka robaczkowego świadczy przeciwko appendicitis acuta. Z kolei taki sam obraz wyrostka robaczkowego, jak opisano powyżej, ale z obrzękiem jelita biodrowego nieprzekraczającym $5 \mathrm{~mm}$ i bez cech jego przekrwienia sugeruje istnienie appendicitis acuta. Zgrubienie kątnicy zdarza się z różną częstością w obu sytuacjach klinicznych, jednak w appendicitis acuta nie towarzyszy mu zgrubienie i przekrwienie ścian jelita biodrowego. later, upon the publication of Ripollés et al. research, the situation complicated ${ }^{(5)}$. The appendixes, which they considered affected by the granulation process in the course of Crohn's disease, demonstrated the features of hyperemia in $72 \%$ of cases (the cause may have been a more sensitive Doppler). After using a multivariate logistic data analysis, the authors concluded that ileum thickening above $5 \mathrm{~mm}$ with the features of hyperemia as well as simultaneous thickening and hyperemia of the appendix wall indicates the lack of appendicitis acuta. However, the same presentation of the appendix but with ileal edema not greater than $5 \mathrm{~mm}$ and without hyperemia suggests appendicitis acuta. Cecal thickening occurs with various frequency in both clinical situations but in appendicitis acuta, it is not accompanied by thickening and hyperemia of the ileum.

\section{Piśmiennictwo/References}

1. Smereczyński A, Gałdyńska M, Bojko S, Lubiński J, Deręgowska A: Znaczenie ultrasonografii w diagnostyce jersiniozy. Ultrasonografia 2007; 7 (29): 35-39.

2. Smereczyński A: 29-letnia kobieta bez dolegliwości, z przyśpieszonym OB. Zagadka USG. Med Prakt 2007; 11: 133-135.

3. Smereczyński A, Gałdyńska M, Lubiński J, Bojko S, Król M, Ostasz O: Techniki badania usg wyrostka robaczkowego. Ultrasonografia 2005; 5 (23): 65-68.

4. Sarrazin J, Wilson SR: Manifestations of Crohn disease at US. Radiographics 1996; 16: 499-520; discussion: 520-521.

5. Ripollés T, Martínez MJ, Morote V, Errando J: Appendiceal involvement in Crohn's disease: gray-scale sonography and color Doppler flow features. AJR Am J Roentgenol 2006; 186: 1071-1078. 